\title{
MedienPädagogik
}

Zeitschrift für Theorie und Praxis der Medienbildung

Themenheft Nr. 34:

Forschung und Open Educational Resources - Eine Momentaufnahme für Europa Herausgegeben von Markus Deimann

\section{Theory And Policy - OER On Their Way Into Practice}

Petra Missomelius

\begin{abstract}
This paper treats open educational resources (OER), specifically in the context of processes related to education policy. Of importance in this regard are the different understandings, positions, perspectives and focal points of the participant actors from the fields of educational research, practical education and education policy. Those involved approach the politically virulent subject of OER from their respective technical or career-specific perspectives and have one (more or less weighty) aspect of the OER movement in mind, which is intended to gain admission to the education strategies being constructed. In particular, two case studies are examined: first, the formulation of Germany's education policy strategy, "Bildung in der digitalen Welt» ["Education in a Digital World»], which was developed in 2016 by the Kultusministerkonferenz (KMK) [the standing conference of education ministers of the federal states] with the participation of professional associations; second, the curriculum formulated 2017 by the Österreichisches Bundesministerium für Bildung (BMB) [Austrian Federal Ministry of Education] comprising $a$ "Binding Digital Competence Exercise» in schools. The paper examines the various positions and retraces the final version on which all could agree and in which form OER is finally anchored in education planning. After identifying the blind spots in the conceptual anchoring of the idea of OER, the paper considers why attractive aspects, especially for specific actors, remain underexposed and disregarded.
\end{abstract}

OER zwischen Theorie und Praxis: bildungspolitische Realitäten

\begin{abstract}
Zusammenfassung
Der Beitrag widmet sich vor dem Hintergrund der europäischen Debatte dem Thema Open Educational Ressources (OER) im Rahmen von bildungspolitischen Prozessen aus der nationalen Perspektive von Deutschland und Österreich. Der Schwerpunkt liegt dabei auf den Diskussionen in den Jahren 2016 und 2017. Dabei geht es um unterschiedliche Verständnisse, Positionen, Perspektiven und Schwerpunkte der beteiligten Akteure aus der Bildungsforschung, der Bildungspraxis und der Bildungspolitik. Die jeweiligen Beteiligten nähern sich dem auch politisch virulenten Thema OER aus ihrer jeweiligen fachlichen oder auch berufsspezifischen Perspektive und haben einen (mehr oder weniger gewichtigen) Aspekt der OER-Bewegung im Kopf, welcher Eingang in die zu erstellenden Bildungsstrategien finden soll. Konkret geht es dabei um zwei Fallbeispiele: zunächst die Erarbeitung
\end{abstract}

Missomelius, Petra. 2019. «Theory And Policy - OER On Their Way Into Practice». MedienPädagogik 34, (März), 90-100. https://doi.org/10.21240/ mpaed/34/2019.03.01.X. 
der bildungspolitischen Strategie Deutschlands «Bildung in der digitalen Welt», welche 2016 von der Kultusministerkonferenz (KMK) unter Beteiligung von Fachverbänden entwickelt wurde. Des Weiteren ein zu Beginn 2017 am Österreichischen Bundesministerium für Bildung (BMB) erarbeitetes Curriculum einer verbindlichen Übung «Digitale Grundbildung» an Schulen. Der Text lotet die verschiedenen Positionen aus und vollzieht nach, auf welche endgültige Fassung man sich dann hat einigen können und in welcher Form schlussendlich OER in Bildungsplänen verankert wird. Nachdem der Beitrag blinde Flecken in der konzeptionellen Verankerung der Idee von OER ausfindig gemacht hat, werden Überlegungen angestellt, wieso besonders für bestimmte Akteure attraktive Aspekte unterbelichtet und unberücksichtigt bleiben.

\section{Introduction}

This article is based on a lecture held at the «European Conference on Educational Research» (ECER) in 2017, whose title was «Reforming Education and the Imperative of Constant Change: ambivalent roles of policy and educational research». It was discussed at the «Reflecting OER Policies, Conceptualizations, and Practices» session, which focused on the various perspectives of different groups involved in educational processes, their needs as well as practical constraints related to their field of activity. Within the scope of the session mentioned above, Luca Mollenhauer (German Institute for International Educational Research - DIPF) presented the process of setting up a nationwide OER information office for networking and information in Germany. Two other contributions (Rachel Shanks and Theo Hug) presented specific OER projects in Scotland and Austria.

Once the term «open educational resources» (OER) had been coined in Paris sixteen years ago at the transnational UNESCO Forum on the Impact of Open Courseware for Higher Education in Developing Countries (UNESCO 2002), the topic was taken up in many different areas of education. However, the considerations and effort at that time were primarily concerned with OER's potential for developing countries. This is still regarded as the driving force behind innovations in the social and economic development of these countries (UNESCO 2015). Only recently has the concept also begun to be considered in the context of current challenges for educational systems and appreciated as a means to generate innovations in learning and teaching (Orr et al. 2015). This is the starting point for the present text.

In my article I would like to consider why good ideas and well-prepared concepts often fail to be implemented or only enter social reality in a very reduced form. What I find particularly disappointing is the fact that, even when implemented, they often seem rather feeble, deprived of the potential effects these ideas might otherwise have achieved. 
I shall report on the experiences and observations I have made as a media education researcher in my contacts with the field of education policy. Because this is a field report focusing on observations, it differs from a purely theoretical paper both in terms of language and form. I would like to take the strategy of the Standing Conference of the State Ministers of Education «Education in a Digital World» as the starting point for my remarks. I would like first to discuss similarities and differences in Germany and Austria in the approach to the challenges involved in the conceptualization of OER in teaching and learning. As far as the situation in Germany is concerned, I would like to introduce to the discussion the perspectives of education policy, with which I became acquainted in the process of discussing the KMK strategy from the viewpoint of media education as speaker for "Keine Bildung ohne Medien» [«No Education without Media», together with my colleague Sven Kommer], a multidisciplinary education policy initiative in Germany.

From my work in Austria, I would in turn like to add my experiences with the development of the «Verbindliche Übung Digitaler Kompetenzen» [«Binding Digital Competence Exercise»] curriculum, which had to be prepared at short notice in late 2016 by a commission of experts on behalf of the Ministry of Education as a first step toward «School 4.0». These lessons - it is an allotment of hours spread across several years, not necessarily a subject on its own - became binding for schools in October 2018.

My remarks and the accounts of my experiences therefore refer largely to the area of school education and only apply in part to higher education. On the whole, we should also note that there is a very comprehensive paper of nearly fifty pages in Germany, while the published Austrian statements and concepts are rather meager and of a general nature.

\section{OER in the conceptualisation of media education policy in Germany and Austria}

In the German education strategy, OER is mentioned for the first time in connection with enabling teachers to choose suitable education materials from those on offer by commercial publishers and OER. At this point, there is only talk of «suitable quality criteria». The relatively long, detailed section on «educational media» addresses OER, assuming that materials produced by pupils and teachers themselves will be circulated along with commercially published products. The formulation of the strategy attempts to describe the characteristics of OER and, as far as their pedagogical suitability is concerned, states, for instance, that these can be processed suitably for the recipients with regard to heterogeneous learning groups. The quality expectations mentioned in the paper are related to technical aspects and refer to the necessary expansion of former admission requirements and teaching materials. In addition, it likewise treats the topic of OER in detail with regard to the higher education 
sector. This intensity when dealing with OER and how it can be used in education is only briefly mentioned in the official Austrian statements, where a Digital Roadmap Austria was first formulated, which also includes the field of education. In connection with an opening of access to education entailed by digitisation, this Roadmap states that both open and free educational content (OER) was intended to be made accessible.

Concrete measures were first announced in spring 2017, in part by the Ministry of Science and in part by the Ministry of Education. As far as the question of OER in the Austrian curriculum development is concerned, the topic was only added in one of the last steps of preparation thanks to input from the participating media educators. The draft finally adopted by the Austrian government consisted of a prologue on theory, as well as a list of subject matter to be treated (this is where OER also appeared) and a set of competences. The final curriculum, which was now communicated as a guideline to schools, consists only of this list of competences to be taught to schoolchildren. What is more, there was finally a decision taken to divide up the program already compiled into a mandatory and elective portion (at least 64 class hours spread over four school years, and a maximum of 128 class hours if established as an educational focal point or subject on its own). This teaching and learning content, which is supposed to include not only reflection and criticism, but also provide pupils with a knowledge of «licensing models, such as creative commons and OER», is now classified as a voluntary area of specialization. Furthermore, this one-and-ahalf sentence is kept decidedly vague compared to the German concept.

The ministry's digitalization strategy is based on three pillars apart from the «Binding Digital Competence Exercise»: infrastructure and IT equipment, digital learning tools and digitally competent teachers (see Fig. 1). Appropriate advanced training measures are intended to cover this need. 


\section{Das Bild der Digitalen Bildung beruht auf 4 Säulen}

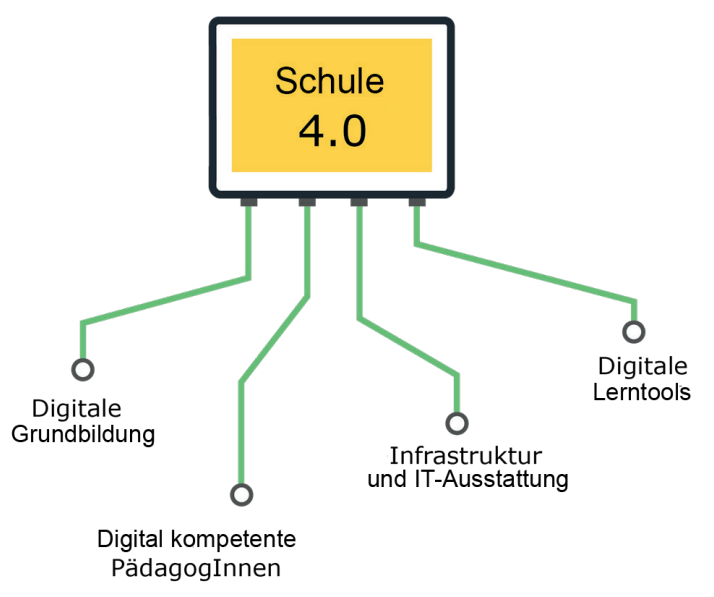

Fig. 1.: The four pillars of digital education presented at a conference in Salzburg on November 24, 2017. [https://eeducation.at/fileadmin/downloads/Folien_17-11-24_eEducationFachtagung.pdf] (c) BMBWF.

It is observed that optional opportunities for advanced training are usually attended by those already highly qualified in the field, reducing this to a case of «preaching to the choir», while those with a real need for further education do not take advantage of these opportunities. An excerpt from a professional group discussion maintains that the latter would best be convinced by «quick and dirty» solutions that are simple enough to convince even skeptics. For this reason, a number of low-threshold offers in the form of ultra-short MOOCs and webinars, as well as «coffee cup learning» at the Virtual College of Education have been set up at the behest of the ministry. It remains to be seen how well these short, tool-focused courses - the slogan for one of which is 20 days, 20 tools - can meet the requirements of schools in the age of digital network culture.

Moreover, the creation or collection of digital learning tools is one of the mainstays of the concept of School 4.0. This is understood as an «eduthek» bringing together what is digitally on offer (this includes much that has been created in connection with computer science education in e-learning). Teachers are seen in this case as purely receptive, and less as producers. Another mainstay is teacher training, which also includes the dissemination of innovative models - OER, however, is not envisaged in this context, or at least not yet. 
Entirely unresolved is the question of how to confront business-oriented actors on the digital tool market for the education sector. In the area of computer-sciencerelated digital competences, network administration has been bound to Microsoft products for some years now, and this is apparently to be further expanded.

\section{Discussions}

A website of the Austria Forum, by contrast, lists a variety of online sources for OER teaching materials related to different types of teaching content and school grade levels. The Austrian Federal Chancellor's Office and the Federal Ministry of Education also commissioned a feasibility study (Schön et al. 2017) conducted by Salzburg Research Forschungsgesellschaft m.B.H. in cooperation with Innsbruck University and the Technical University of Graz. This study takes up the question of how the stakeholders involved can respond to the transformations entailed by the introduction of OER school books (mentioned here are primarily costs and funding models). Again and again, it is clear that the discussion of OER in school is largely unknown in the schools themselves and at best considered as an academic pursuit. There are many reservations to be heard, whose motivations are personal on the one hand, but on the other also institutional. This applies, for instance, to the structural conditions that would be necessary to enable OER to be used in educational work. Austrian school law (SchUG, § 14 of the School Education Act) still explicitly prefers print media. Teachers cling to the expertise of educational publishing companies and the authority of approved teaching materials. Furthermore, they are uncertain not only out of fear of legal consequences, but also related to publishing their own teaching materials.

In the end, six possible scenarios were designed for the present study, starting from specialized literature and stakeholder interviews (teachers, educational policy, school book publishers):

1. No changes in school book activities of the Austrian federal ministries involved

2. Successive additions of OER school books and other OER materials to the school books on offer, funded by the ministries

3. (Additionally) incentivising the development of OER school books through public gratification based on utilization surveys

4. OER school books as a "common option»

5. Completely changing over to OER school books by tying the approval of school books to the OER clause

6. Completely changing over to OER school books through public tenders. 
Currently, Austrian education policy appears to favour Scenario 2. The Federal Ministry of Education is exhibiting the political will to devote itself to expanding OER projects, while Austrian school book publishers are still extremely reserved on this topic. At present, tenders are being accepted by the Innovationsstiftung für Bildung [Innovation Foundation for Education] for the promotion program «Erstellung von digitalen Lehr- und Lernmitteln mit Citizen Science-Methoden» [«Creating Digital Learning and Teaching Materials by Citizen Science Methods»]. In the process, already existing teaching and learning materials are to be revised on the eduthek online platform with the aid of pupils and teaching staff, and finally released as OER. Particularly gratifying from the point of view of media education is the passage stating that the public tenders should expressly place a high value on an aware, discriminating, critical and goal-oriented use of digital media in teaching.

The discussion of the "Binding Digital Competence Exercise» curriculum as part of «School 4.0» has revealed further issues which I have already encountered again and again in the KMK strategy discussion, as well as while working on «Dagstuhl in progress» (a paper treating the three disciplines of computer science and teaching, media education and media studies in the Dagstuhl Declaration of 2016 on «Digital Education»).

Here is an excerpt from one of these discussions:

Computer science teacher to media scholar: "For us computer scientists, practice is when we build something and analysis is theory for us.»

Media scholar to computer science teacher: «Interesting. Our practice is analysis!» (ftzm 2016)

This appears to be symptomatic of the trouble spots revealed by topics at the intersections of various disciplines.

- Terms are understood differently: (if «media» means digital in general, for instance, why is television so widely neglected?)

- Hence the scope/level of reflection is also different (if, for instance, media are understood as systems of symbols starting with language, writing and picture, you think of them in a historical perspective, as well. Topics such as visual literacy show up then.)

- Processes are judged differently (digitization - «mere» transmission (technology as technology) or as changes in media, and thus in culture as well, with effects on perception, worldview and self-image, as well as on social organization (consequences for institutions, for legislation, etc.)). 
If we broaden our thinking to include several disciplinary approaches, then the complexity of the issue also immediately increases (and mirrors education reality better). As is well known, however, complexity can be arduous and difficult to communicate. This is particularly a problem in an emerging field for which the ability to communicate is essential. And this is the challenge for media education in general. Educational and other policy evinces a strong preference for short and clear statements, the aim being to keep things very simple. The idea of open resources (as understood historically, sociologically and educationally) calls for more elaboration (Missomelius et al. 2014; Missomelius and Hug 2016). It is a challenge for media scholars to access this mindset and to make use of the vocabulary that best describes the task.

The concept of OER certification at Austrian institutions of higher education (2017) as an Austrian example

The Forum of New Media in Austria, consisting of actors from the field of e-learning, published a concept for the certification of open educational resources at Austrian institutions of higher education in May 2017.

The concept, commissioned by the Federal Ministry of Science, Research and Economy, envisages an OER certification both for educators at institutions of higher education as well as for the institutions themselves. The certification as suggested is intended to be carried out by a central facility whose composition must be decided by the Federal Ministry. The concept suggested initiating a national office of this sort by the end of 2017, which would then be able to start work in 2018.

The ministry plans to anchor open resources with the universities in the next performance agreement period (Zielvereinbarungen 2019 to 2021). In addition, FNMA has launched a MOOC on OER. Both the certification concept as well as the MOOC see the topic of OER from an exclusively operative point of view, dealing only with technical and legal problems. Educational, structural, cultural, reflexive or even theoretical aspects are apparently considered to be irrelevant in this connection.

I was able to bring up this topic when I had an opportunity to talk with one of the authors, and the reason he gave for the limitation to formal characteristics was that anything else would be too «confusing and subject dependent» for a regulation.

\section{Blind spots}

This brings us to the blind spots. Reducing the concept of OER to teaching materials and questions of technological implementation largely leaves out the cultural, social and pedagogical aspects of the idea of OER. Thus it can be referred to as a weak form of OER. This reduction process is comparable with the one affecting media education 
when it is drafted as a process of technologising education and introducing digital educational media into the education process. Following the definition in the OECD paper of 2012, Fig. 2 tries to clarify the different ways of understanding the various approaches and their conceptual dimensions. Minimalistic conceptions reduce OER to digitizing teaching materials and pooling them in portals and repositories, followed by considerations of how to use digital tools in class (for example, wikis). At present, there are plenty of websites on learning tools where prepared learning opportunities can be viewed and used.

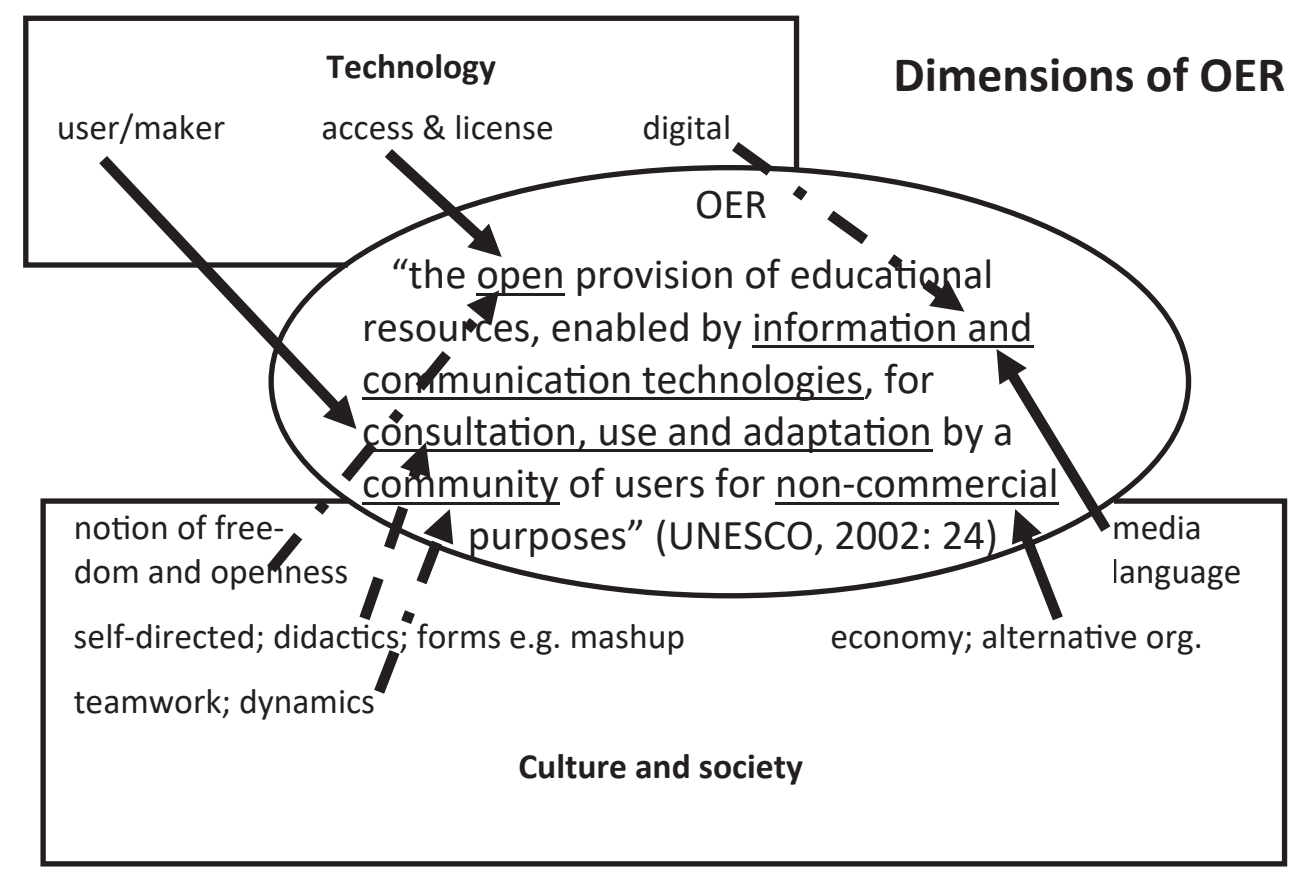

Fig. 1.: Different theoretical presumptions on the dimensions of OER by Petra Missomelius.

\section{Lessons learned}

When a media scholar looks at OER as part of a type of media education informed by media studies, she sees that many concepts and most promotional approaches still give too little importance to the didactic incorporation of OER, to a new way of thinking about pedagogical approaches and questions related to the organization and philosophy of education - which, from the perspective of media studies, is what is actually interesting about OER. Basically, this refers to the innovative potential of OER, which is tacitly assumed and furthermore expected to entail positive change. Reflecting on these processes appears to be considered unnecessary. 
However, we would be negligent were we not to give thought to the implications of changing media on world views and self-images, to the changing dynamics and conceptions of knowledge caused by virtualisation, and not to take account of these in our conceptions from the outset. This would enable context-sensitive reflection for future-oriented developments of OER. This would be a strong form of OER.

In my observations, I have noted that these differing ways of understanding OER are closely related to specialized approaches that allow a particular perspective on a field, while other areas are given too little attention or none at all. Thus OER provide a clear example of how decisive dimensions of media education are disregarded in discussions and implementation, and reduced more or less unthinkingly to technological applications.

The extent to which OER involve not only teaching and learning WITH media, but also teaching and learning ABOUT media, remains to be clarified. Otherwise there is only education WITH media but no media education.

To sum up, and considering the case described here of how education policy ensconced OER in concepts of education, the lesson we can learn is that we must always expect differences in the connotations of media education-related terms in discussions of education policy (this has been a familiar occurrence since the term «media competence» was first diluted) and that we who engage in media studies and media education will therefore always have to make an effort to more clearly specify the terms and content when communicating with the relevant institutions. This is the only way to guarantee that technologies will not be treated as black boxes, but rather clear the way for broad segments of society to reflect on technology-induced structures and functions, as well as their implications. Rather than merely teaching user competence, for instance, it is vital for us to consider such current phenomena as hate speech, filter bubbles, etc. from these angles if we wish to truly understand them.

\section{References}

Austria Forum. 2017. «Liste (aller) Webseiten, die in Österreich OER Unterrichtsmaterialien anbieten». https://austria-forum.org/af/Unterrichtsmaterialien/Open_Educational_Resources/OER_Angebote_\%C3\%96sterreich.

Bundeskanzleramt und Bundesministerium für Wissenschaft, Forschung und Wirtschaft (BMBWF). 2016. «Digital Roadmap. Die digitale Strategie der österreichischen Bundesregierung». https://www.digitalroadmap.gv.at/.

Forum Neue Medien Austria (fnma). 2017. «Konzept OER-Zertifizierung an österreichischen Hochschulen». https://www.fnm-austria.at/fileadmin/user_upload/documents/Buecher/ OER_Labeling_2017.pdf. 
Frankfurter Technologiezentrum [:Medien] (ftzm). 2016. «Klausurtagung Dagstuhl-Dreieck in progress». Internal protocol.

Innovationsstiftung für Bildung. 2018. «Welche digitalen Lehr- und Lernmittel brauchen wir?» https://innovationsstiftung-bildung.at/de/foerderungen/ausschreibungen/.

Kultusministerkonferenz Deutschland (KMK). 2017. Strategie «Bildung in der digitalen Welt». https://www.kmk.org/fileadmin/Dateien/pdf/PresseUndAktuelles/2016/Bildung_digitale_Welt_Webversion.pdf.

Missomelius, Petra et al., eds. 2014. Medien - Wissen - Bildung: Freie Bildungsmedien und Digitale Archive. Innsbruck: iup. https://www.uibk.ac.at/iup/buch_pdfs/freie-bildungsmedien_web.pdf

Missomelius, Petra, and Theo Hug. 2016. «Opening up Education: Opportunities, Obstacles and Future Perspectives». In The Philosophy and Theory of Open Education: Peer Learning and the Intellectual Commons, edited by Markus Deimann and Michael A. Peters, 31-50. New York: Peter Lang.

Österreichisches Bundesministerium für Bildung, Wissenschaft und Forschung (BMBWF). 2017. «Digitale Grundbildung». https://bildung.bmbwf.gv.at/schulen/schule40/dgb/index.html.

Schön, Sandra, Katharina Kreissl, Leonhard Dobusch, and Martin Ebner. 2017. «Mögliche Wege zum Schulbuch als Open Educational Resources (OER). Eine Machbarkeitsstudie zu OERSchulbüchern in Österreich 2017». https://bildung.bmbwf.gv.at/schulen/sb/machbarkeitsstudie_schulbuch_oer.pdf?67bjmg.

UNESCO. 2002. «Forum on the impact of Open Courseware for higher education in developing countries: Final report». http://unesdoc.unesco.org/images/0012/001285/128515e.pdf.

UNESCO. 2015. «Incheon Declaration: Education 2030». https://en.unesco.org/world-education-forum-2015/incheon-declaration. 